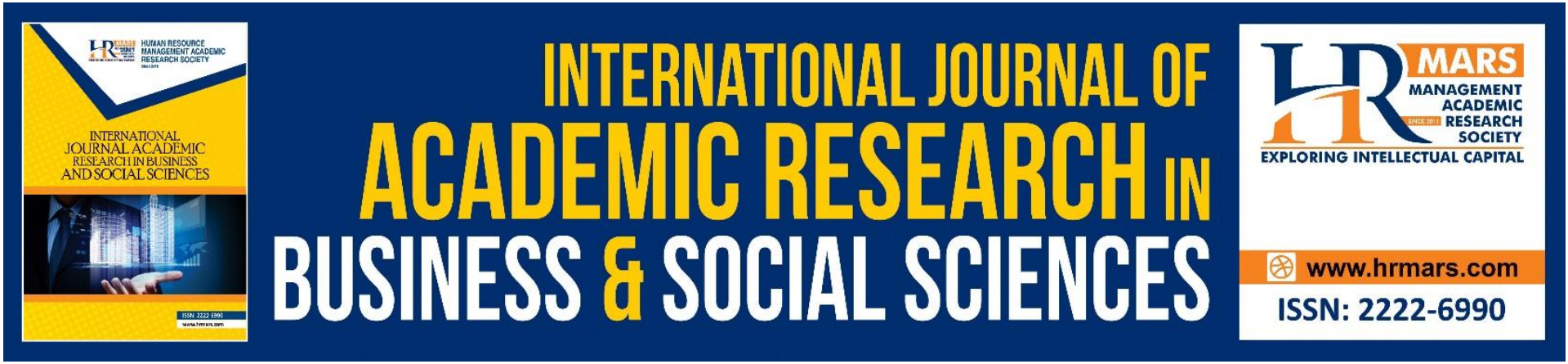

\title{
Testing Weak Form Efficiency in Indian Market with Special Reference to Banking Sector
}

\section{Tamilselvan, Sathyamoorty. Manikandan}

To Link this Article: http://dx.doi.org/10.6007/IJARBSS/v11-i5/9972

DOI:10.6007/IJARBSS/v11-i5/9972

Received: 05 April 2021, Revised: 28 April 2021, Accepted: 11 May 2021

Published Online: 25 May 2021

In-Text Citation: (Tamilselvan \& Manikandan, 2021)

To Cite this Article: Tamilselvan, M., \& Manikandan, S. (2021). Testing Weak Form Efficiency in Indian Market with Special Reference to Banking Sector. International Journal of Academic Research in Business and Social Sciences, 11(5), 439-452.

Copyright: (c) 2021 The Author(s)

Published by Human Resource Management Academic Research Society (www.hrmars.com)

This article is published under the Creative Commons Attribution (CC BY 4.0) license. Anyone may reproduce, distribute, translate and create derivative works of this article (for both commercial and non-commercial purposes), subject to full attribution to the original publication and authors. The full terms of this license may be seen at: http://creativecommons.org/licences/by/4.0/legalcode

Vol. 11, No. 5, 2021, Pg. 439 - 452

Full Terms \& Conditions of access and use can be found at http://hrmars.com/index.php/pages/detail/publication-ethics 


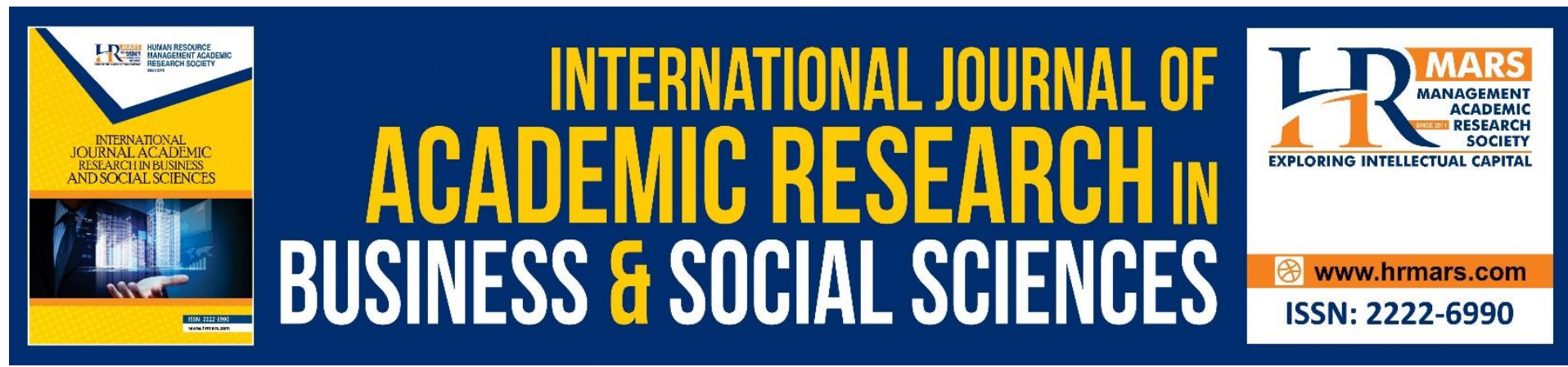

\title{
Testing Weak Form Efficiency in Indian Market with Special Reference to Banking Sector
}

\author{
Dr. M. Tamilselvan, Mr. Sathyamoorty. Manikandan \\ Faculty of Finance \& Accounting,Departmet of Business studies, Ibri College of Technology, \\ Sultanate of Oman
}

\begin{abstract}
Market Efficiency is an important area of research in behavioral finance and lot of effort has been expended for improving econometric models since rational market facilitates in to better investment and risk management. In this direction this paper attempts to evaluate the random walk hypothesis by using unit root tests in the context of Indian stock market. The main objective of the stock market efficiency is rational utility maximization where the investors are not consistently earning abnormal return using the information and beating the market. The Efficient Market Hypothesis (EMH) asserts that the stock prices reflect the available information about the stocks fundamental. The study has used the daily closing price of banking sector index and 12 banking stocks listed and actively traded in National Stock

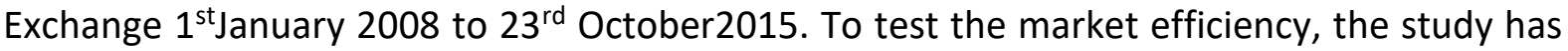
used three prominent unit root tests such as Augmented Dickey-Fuller test (ADF), PhillipsPerron test (PP), and Kwiatkowski-Phillips-Schmidt-Shin test statistic (KPSS) test. The test results reveal that the NSE-Bank Index and its 12 stocks are found to be weak form inefficient, so that trading strategies can be formulated by investors to gain abnormal returns. There is possibility of earning abnormal return using naïve buy and hold strategy.
\end{abstract}

Keywords: Random Walk Hypothesis, Rational Utility, Unit Root Test

\section{Introduction}

Stock market is the most integralpartof a financial system. Stock market deals in shares of corporate and it is reflected by share prices. In recent years, the intellectual curiosity of researchers and investors has much focused to examine the efficiency of the stock market. This is partly due to the advent of new economic policy;the Foreign Institutional Investors (FIls) began investing in the Indian stock market due to low price earnings ratio. Many factors, such as enterprise performance, dividends, stock prices of other countries, gross domestic product, exchange rates, interest rates, current account, money supply, employment, their information etc. have an impact on daily stock prices (Kurihara, 2006).

\section{Global Economic Competitive Mechanism}

There are internal and external factors affecting and determining the economic growth of a nation. They are persistent slow growth, high inflation, exchange rate instability on account of capital outflows, fiscal and current account imbalances and lower investment. 
The International Monetary Fund(IMF) had predicted that the year 2014 would be the transitional period. But the global economy suffered from aggravation of sovereign debt in euro zone, poor performance of Chinese and Russian economies and oil price drop. The global economy is expected to grow from 2.6\% (2014) to 3\% in (2015), 3.3\% (2016) and 3.2\% in 2017. From developing countries from $4.4 \%$ (2014) to 4.8\% (2015), 5.3\% and 5.4\% in 2016 and 2017 respectively. There are four major factors identified for the economic recession such as 1 ) Weak international trade, 2) Raising interest rate and market volatility, 3) Budgets of oil producing countries and 4) Euro zone and Japan entering into long period recession. Apart from this Russia is affected by the restriction imposed by west on its position of Ukraine crisis and Iran's controversial nuclear problem. If the political problems remain unsolved, the global economy will slow in 2015. In these crucial economic circumstances US achieved growth in exchange rate, operation rate, cancellation of quantitative easing. The sudden increase of shale oil production by US made a cascade effect on international oil price which affect the economy and budgets of oil producing nations. In the first half of 2014 June the oil price touched $115 \$$ and it came down to $53 \$$ per barrel in the second half of 2014 . Hence in the last 16 months the US exchange rate increased and 36 currencies declined against USD. Last year the US index increased by $12 \%$ in contrast the Russian currency declined by $39 \%$. China recorded the highest fall in 24 years. Brazil and other economies in Asia, South America and Middle East have also declined. ${ }^{1}$

Indian economy witnessed a vigorous growth for two successive years even after financial crisis. Since then it has decelerated, in 2013 the GDP growth was 4.5\%. In 2014, it has marginally picked up to $4.7 \%$ due to increase in agriculture sector growth, net exports, rupee depreciation, and curbing gold imports. The overall growth was sluggish due to reduction of investment and private consumption expenditure. The GDP achieved a higher growth in the last 10 quarters with $5.7 \%$ in the first quarter of 2015 . The growth was driven by improvement investment demand and exports. As well as rise in manufacturing and mining sector output. The reduction of uncertainty on the legal and regulatory frame work boosted the investors' confidence in the economy. The GDP in second quarter of 2015 recorded a mild slow down with $5.3 \%$. It was driven by the community, social and personal services. The industrial sector underperformed in the second quarter. The foreign direct investment (FDI) is more significantly related to the GDP growth of the nation. The incremental growth of FDI is the good sign of economic growth. The financial system facilitates faster economic growth through pooling fund, encouraging and mobilizing overseas investments, risk diversification and liquidity management. ${ }^{2}$

\section{Banking Sector Development in India}

The robust Indian banking sector consists 157 scheduled commercial banks with 1.8 trillion USD banking assets, 1.4 trillion banking deposits and $90 \%$ market share. It contributes $27.5 \%$ employment in the total financial sector employment ${ }^{3}$.The 1991 new economic policy has resulted in theconception of various private sector banks. This has sparked a boom in thecountry's banking sector in the past two decades. The revenue of Indian banksgrew fourfold from US\$ 11.8 billion to US\$ 46.9 billion, whereas the profit aftertax rose nearly nine-fold

\footnotetext{
${ }^{1}$ Annual Reports (2010-2014) - Muscat Security Market

${ }^{2}$ Over View of Indian Security Market (2014)

${ }^{3}$ India Banking Sector Report-April,2014
} 
from US\$ 1.4 billion to US\$ 12 billion over 2001-10.Thisgrowth was driven primarily by two factors. First, the influx of Foreign DirectInvestment (FDI) up to 74 per cent with certain restrictions. Second, theconservative policies of the Reserve Bank of India (RBI), which have shieldedIndian banks from recession and global economic turmoil.

Banking Structure in India

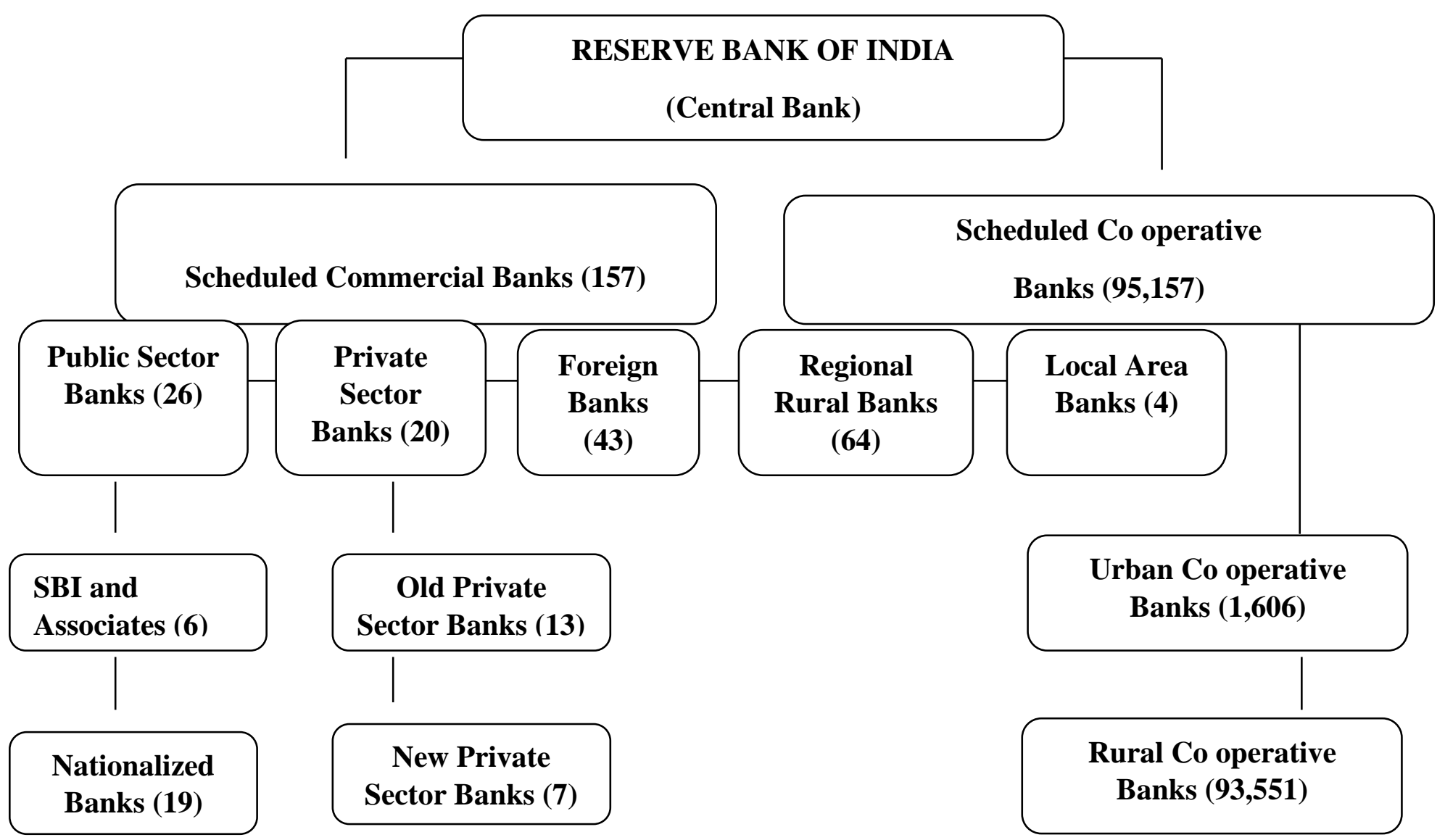

Other Public

Sector Bank (1)

\section{Source: Indian Banking Sector Report, April - 2014}

The Bankexisan index tracking the performance of important banking sector stocks, and hasgrown at a compounded annual growth rate (CAGR) of approximately 20 percentover 2003-2012.The high CAGR exhibited by India's Bankex demonstrates the industry's resilienceto recession and economic instability. This resilience primarily stems from twofactors.First, the highly regulated Indian banking sector restricts exposure tohigh risk assets and excessive leveraging. Second, Indian economy's overallgrowth rate has been much higher than other economies worldwide.However, the recent crisis in the euro zone is likely to affect the Indian economyand in particular the country's banking sector. 


\section{Banking Products}

\begin{tabular}{|c|c|c|}
\hline \multicolumn{3}{|c|}{ RETAIL BANKING } \\
\hline LOAN PRODUCTS & DEPOSIT PRODUCTS & OTHER OFFERINGS \\
\hline $\begin{array}{l}\text { Auto\&Personal Loan } \\
\text { Construction Equipment } \\
\text { Finance } \\
\text { Credit/Debit cards } \\
\text { Gold Loan } \\
\text { Agri/Tractor/Education loans }\end{array}$ & $\begin{array}{l}\text { Savings Accounts } \\
\text { Current Accounts } \\
\text { Fixed\&Recurring deposits } \\
\text { Corporate Salary Account }\end{array}$ & $\begin{array}{l}\text { Depository Accounts } \\
\text { Mutual Funds/Insurance/Gold } \\
\text { Sales } \\
\text { Private Banking } \\
\text { NRI Bill Payment } \\
\text { Forex Service } \\
\text { POS Terminals }\end{array}$ \\
\hline \multicolumn{3}{|c|}{ WHOLESALE BANKING } \\
\hline COMMERCIAL BANKING & TRANSACTIONAL BANKING & INVESTMENT BANKING \\
\hline $\begin{array}{l}\text { Working Capital } \\
\text { Term Loans } \\
\text { Wholesale Deposits } \\
\text { Forex\&Derivatives } \\
\text { Letter of Credit Guarantees }\end{array}$ & $\begin{array}{l}\text { Cash Management } \\
\text { Custodian Clearing Services } \\
\text { Correspondent Banking } \\
\text { Tax Collection } \\
\text { IPO -Underwriting }\end{array}$ & $\begin{array}{l}\text { Debt Capital Markets } \\
\text { Equity Capital Markets } \\
\text { Project Finance } \\
\text { M\&A advisory }\end{array}$ \\
\hline \multicolumn{3}{|c|}{ TREASURY OPERATIONS } \\
\hline TREASURY PRODUCTS & OTHER FUNCTIONS & OFFERINGS \\
\hline $\begin{array}{l}\text { Forex\&Derivatives } \\
\text { Debt - Equity }\end{array}$ & $\begin{array}{l}\text { Asset Liability Management } \\
\text { Statutory Reserve } \\
\text { Management }\end{array}$ & $\begin{array}{l}\text { Leasing Operations } \\
\text { Dealership Business } \\
\text { Third Party product distribution }\end{array}$ \\
\hline \multicolumn{3}{|c|}{ Source:Dun\&Bradstreet-Bank Website } \\
\hline
\end{tabular}

The RBI's Financial Stability Reportestimates the claim of European Banks on India at approximately 8.6 per cent ofthe country's GDP.Further, the recent implementation of the Basel IIIguidelines may also force European banks to deleverage significantly. International Monetary Fund (IMF) suggests that these banks will deleverageup to US\$ 2.6 trillion by the end of 2013 especially from the sale of securities andnon-core assets. This will see the credit supply to businesses shrinking by 1.7 percent, thereby driving Indian companies to borrow from the Indian banks at ahigher cost in times of inflation and in a period of depreciation in the value ofrupee. The non-performing assets (NPAs) of banks were pegged at 2.9 percentin the fourth quarter of 2011, and are expected to rise to 3.5 per cent by 2012 . Allthese factors might hamper the performance of the Indian banking sector. However, amongst positive initiatives taken by the government, the RBI mandatedbanks to maintain 70 per cent of the provision coverage ratio of their bad loans ason September 2010, thereby mitigating the effect of NPAs to a certain extent. The report forecasts that India's GDP growth will take the size of the country's banking sector, to the thirdlargest in the world by 2025. Banking in India is moderately consolidated, with the top 10 playersaccountingfor approximately 60 per cent of the total industry. The Indian banking sector ismajorly dominated by public sector banks. The performance of the Indian economy is one of the strongest drivers for thebanking industry's growth and the averageGDP growth of 8.1 per cent expected over 2011-16 will facilitate the expansion ofthe banking sector. The government policies bringing in monetary stability willalso benefit and shield the industry from global economic or political turmoil. However, a keen observation reveals that the bankingsector has outperformed the market 
2010 onwards. A boost in the banking industry is also expected from the rising per capita incomein India, which along with a growth in the earning population of the country willlead to a higher number of people utilizing banking services. The percapitaincome growth is expected to be a major driver, as the Indian population primarilycomprises of conservative spenders who invest in property and other necessities. Higher disposable income will increase the retail credit, with consumers investingin a wide range of products. A World Bank Survey conducted in 2011 revealed that only 35 per cent of all adultsin India had a bank account with a formal banking institution. Thisrepresents a massiveopening that financial institutions in the country can leverage upon for futuregrowth. Thelndian government has advised banks to open at least one branch in villageswitha population of more than 2,000, and also cover the peripheral villages. Banks arealso required to formulate a board approved Financial Inclusion Plan (FIP), theimplementation of which will be monitored by the RBI. ${ }^{4}$

\section{Conceptual Background of Market Efficiency}

The investors generally adopt two prominent investment approaches such as fundamental and technical analysis. The first approach is finding all the mispriced stocks in the market where as the second approach is seeming the price movements. The actual stock price of a particular stock in a given time is away from the intrinsic value determined by the fundamental analysis due to systematic error made by the investors. The error is likely to happen in order to earn more return appropriate to risk level. Eventually, the investment decisions are made out of intertemporal choices of the investors. So, a separate field of finance called 'behavioral finance' has evolved to analyze and explain the unexpected distress in the stock market using efficient market hypothesis (EMH). ${ }^{5}$ The informational efficiency of the security market is referred to efficiency market hypothesis. In the efficient market hypothesis, the investors are not consistently earning abnormal return using the informational set. The excess profit earned from naive buy and hold strategy is abnormal return. ${ }^{6}$

\section{Relevance Approach to EMH}

French mathematician Louis Bachelier demonstrated in his work "Theorie de la speculation" that an asset's price accurately reflects all known information about it. There is no such thing, in his view, as an undervalued or overvalued asset, the market is perfect reflection of the underlying fundamentals. Often the asset prices are changing dramatically towards a rational and automatic response to the arrival of new information. ${ }^{7}$ University of Chicago economics professor EugeneFama constructed a mathematical model and proved that the markets are rational and efficient. He believed that the price of any asset at any time is completely correct. The asset cannot be overvalued or undervalued. The current price is the right price. This theory hypothesized that all public information is immediately and accurately incorporated in the asset's price, and any further price change must depend on things not yet known. Therefore predicting the future price movement and beating the market is impossible. Eventually, in 1970s the Efficient Market Hypothesis had become a

\footnotetext{
${ }^{4}$ The Indian Banking Sector Recent Developments, Growth and prospects, India Brand Equity Foundation

${ }^{5}$ Introduction to security Analysis, Icfai publication

${ }^{6} R$.Vaidyanathan,(1994) Efficiency of the Indian Capital Market, Indian Journal of Finance and Research

${ }^{7}$ NourielRoubini and Stephen Mihm, Crisis Economics Penguin Publisher - Cnanda
} 
conventional wisdom. ${ }^{8}$ Eugene Fama (1970) reported that anomalies like serial dependencies in stock market return. The excess volatility is considered to be more dangerous than other financial anomalies like January effect or day of the weak effect. The prices are changing due to "Sun pots" or animal sprit or just mass psychology. According to Efficient Market Modelthe current stock price is the product of the stock's fundamental price and the coefficient of mathematical expectation on information. The efficient model can be written as $P_{t}=E_{t} P_{t}$ * where $E_{t}$ refers to mathematical expectation conditional on public information available at time " $\mathrm{t}$ ". ${ }^{9}$

\section{Irrelevance Approach to EMH}

In the 1990s, a lot of the focus of academic discussion shifted away from this econometric analysis of time series on prices, dividends and earnings towards developing models of human psychology as it relates to financial markets. The field of behavioral finance developed. One of the oldest theories about financial market is a price -to-price feedback theory. When speculative price goes up creating success for some investors, this may attract public attention, promote word of mouth enthusiasm, and heighten the expectation for further price increase. The talk attracts attention to "new era" theories and popular models" that justify the price increase. Yale Economist Shiller (2003) argued in his book Irrational Exuberance that 2000 stock market bubble transmitted by word of mouth and media. The cognitive psychology research emphasized that human judgment of the probability of future events show systematic biases. The efficient market theory emphasizes that when irrational optimists buy a stock, smart money sells, and when irrational pessimist sell a stock smart money buys, thereby eliminating the effect of irrational traders on market price. Barberis and Shlefer (2002) presenteda numerical implementation and concluded that Prices deviate substantially from fundamental values as stylesbecome popular or unpopular. For an arbitrageur witha good model of prices, thereare substantial profits to be made from a combination of contrarian and momentumtrading. On the other hand, despite the fact that markets are inefficient, prices arevery noisy. ${ }^{10}$

\section{Review of Literature}

Scottish thinker Adam Smith in his wealth of nation advanced the now famous representation of the 'invisible hand' to capture the seemingly unbelievable process by which the selfish and divergent interest of individual economic actors somehow merges into a self-regulating economic system. The nineteenth century economics accepted that the markets are fundamentally self-regulating always moving towards some magical equilibrium. David Ricardo and Alfred Marshall refined Smith's insights and built a mathematical structure to prove this point. Shiller (1980) emphasized that the stock price movements are not rational; they are irrational desires of the crowd. Moustafa (2004) examined and proved that the UAE market is weak form efficient. Worthington (2006) showed that all the Asian and four developed markets are weak-form inefficient. Phukubje (2006) suggested that there is no strong support for weak-form inefficiency in South African futures markets for wheat and

\footnotetext{
${ }^{8}$ NourielRoubini and Stephen Mihm, Crisis Economics Penguin Publisher - Cnanda ${ }^{9}$ Robert J.Shiller (2003) From Efficient Markets Theory to Behavioral Finance, Journal of EconomicPerspectives.pp 84-85

10 . Nicholas Barberisa, *, Andrei Shleiferb.Style investing, Journal of Financial Economics 68 (2003) 161-199
} 
sunflower seeds. Niblock ( 2007) evaluated and supported Chinese stock markets are weak form inefficient. Gimba (2009) found the weak form inefficiency in Nigerian market. Asma (2010) studied about the weak form efficiency of Bangladesh stock market and resulted that the market is weak form inefficient. Gupta (2011) showed the mixed evidence in two different periods in Indian market. Khan (2011)studied and found that Indian Capital market neither follow random walk model nor is a weak form efficient.AbdulHaque (2011) revealed that the Pakistani stock prices are not weak form efficient. Abushammala (2011) proved the inefficiency of the Palestine market. Gerasimos (2011) studied the randomness of US ETF market and found that the US ETF price movement is not random. Abdullah (2012) investigated the weak form efficiency of Suudi Stock Market and the results concluded that the market is weak form inefficient during the study period. Mayowa (2012) studied Nigerian Capital Market and found that market is efficient in the weak form. Nisar (2012) suggested that none of the four majorstock markets of south-Asia follows Random-walk. Shaker (2013) concluded that daily prices and returns do not follow random walks in Finnish and Swedish stock markets. Vladimir (2013) showed the Ukraine stock market follows random walk hypothesis. Izzeddien(2014) showed that the Jordan stock market is inefficient at the weak form level.llona Shiller (2014)studied and found the weak form efficiency in Canadian equity market.Syed Tauseef Raza Gilani(2014) found that the behavior of stock market of Islamabad is random.Tamilselvan(2015) showed the Indian market is weak form inefficient relating to nifty stocks and automobile sector.

\section{Statement of Problem}

There are two prominent schools of thoughts on random walk model such as relevance and irrelevance approaches. In this context, the first approach supported by Eugene Fama emphasizes that the market is completely reflecting all the available information on the stock price movement. Hence, it is impossible to outperform the market without assuming additional risk. In contrast, the irrelevance approach of market efficiency supported by Robert shiller evidently proves that there was a persistent deviation from a share's 'correct' value and cannot be deemed random. Hence, it is figured out that the share price movement is not always random due to various reasons. The empirical war between Robertshiller and Eugene Fama is taken as motivation to test whether the fund managers, high net worth individuals, Flls, and investment community can earn abnormal return adopting technical analysis or not from banking sector investment in Indian market.

\section{Objectives of the Study}

To understand aboutthe global economy and banking sector developments in India To understand the relevance and irrelevance approaches to Random Walk hypothesis To review the empirical evidences of weak form efficiency in global capital markets. To understand about the econometric models used to detect the random walk hypothesis. To empirically investigate the randomness of stock price movement of NSE-Bank Index and banking stocks using unit root tests.

\section{Data and Methodology}

In this empirical study secondary data was used. The banking index and stocksfor the current study were chosen from National Stock Exchange. The data relating to daily closing price of 12 bank stocks and bank index were used. The daily closing price of NSE- Bank Index and stock prices were obtained from National Stock Exchange Website for the period of eight 
years between January, 2008 - October 2015. The data has been analyzed adopting Augmented Dickey-Fuller test (ADF), Phillips-Perron test (PP), and Kwiatkowski-PhillipsSchmidt-Shin test statistic (KPSS) in E-Views-9.

\section{Unit Root Test}

The high frequency time series data is assumed to be non - stationary at level and it produces time varying variance. This unique character of the economic variable is called as random walk hypothesis in behavioral finance. Hence, the existence of stationarity and non stationarity are being detected adopting an econometric model called unit root test. In most of the cases the unit root is not found in the time series data while the data is converted in to first difference or second difference. In econometric analysis, the statistical properties like mean and variance of a time series data should be constant for long time. The time series data set should be stationary. Stationary refers to a horizontal time series in which the observation revolves around its mean. Such series are otherwise called mean reverting series. If the data is not stationary, it is difficult to use the econometric models in analysis and forecasting. ${ }^{11}$ In a model with a lagged dependent variable, it is assumed that the coefficient is less than 1 absolute value to avoid explosive behavior. In some situations, the coefficient might be exactly 1 . The simplest of this class of model is the random walk model, given by $y_{t}=y_{t-1}+u_{t}$. This means that the value at time $t$ is equal to its value in the previous period plus random shock. Equivalently, the change in value in the previous period to next is a pure white noise random variable.In this case $\operatorname{Var}\left(y_{t}\right)=\operatorname{Var}\left(y_{-1}\right)+\operatorname{Var}\left(u_{t}\right)$. By repeated substitutions, it is found that the variance of $Y t$ goes to infinity as to $t$ goes to infinity. This situation is known as the unit root problem. ${ }^{12}$ If we ignore the unit root and estimate the model as $y_{t}=p Y_{t-1}+u_{t}$, then it can be shown that the distribution of OLS estimator of $\mathrm{p}$ is not centered at 1 and the corresponding t-statistic does not have the student's t distribution (Dickey and Fuller, 1979). Therefore, the usual t-test for $p=1$ does not apply. Hence, in thisstudy the stationarity is verified using Augmented Dickey - Fuller -Phillip Perron Kwiatkowski-Phillips-Schmidt-Shintests.

\section{Augmented Dickey - Fuller Test (ADF)}

$$
\Delta \lambda_{t}=\alpha_{0}+\alpha_{2} t+\sum_{i=l}^{k} \beta \Delta \lambda_{t-1}+\varepsilon_{t}
$$

Where, $\lambda_{t}$ denotes the daily price of the individual stock at time " $\mathrm{t}$ " and " $\beta_{1}$ " is the coefficient to be estimated, $\mathrm{k}$ is the number of lagged terms, $\mathrm{t}$ is the trend term, $\alpha_{2}$ is the estimated coefficient for the trend, $\alpha_{0}$ is the constant, and $\varepsilon$ is white noise. MacKinnon's critical values are used in order to determine the significance of the test statistic.

\section{Phillips-Perron (PP) Test}

Phillips and Perron (1988) suggest an alternative (nonparametric) method of controlling of serial correlation when testing for a unit root. Phillips and Perron use nonparametric statistical methods to take care of the serial correlation in the error terms without adding lagged difference terms. Since the asymptotic distribution of the PP test is the

11 .Ash Narayan Sah, Data Analysis Using Microsoft Excel, Excel Books.pp 165

${ }^{12}$ RamuRamanathan, Introductory Econometrics with Applications, Fifth edition, South Western Publication-pp455 
same as the ADF test statistic.The PP method estimates the non-augmented DF test equation and modifies the t-ratio of the coefficient so that serial correlation does not affect the asymptotic distribution of test statistic. The advantage of Phillips and Perron test is that it is free from parametric errors. PP test allows the disturbances to be weakly dependent and heterogeneously distributed. The PP test is based on the following statistic. ${ }^{13}$

$$
\prod_{\alpha}=t_{\alpha}\left(\frac{\gamma_{0}}{f_{0}}\right)^{1 / 2}-T \frac{\left(f_{0-} \gamma_{0}\right) \varepsilon_{t}(\alpha)}{2 f_{0}{ }^{1 / 2} \varepsilon}
$$

Where $\alpha$ is the estimate, and $t_{\alpha}$ is the ratio of $\alpha$ and $\varepsilon_{t}(\alpha)$ is coefficient standarderror and $\varepsilon$ is the standard error of the test regression. In addition $y_{0}$ is a consistent estimate of the error variance. The remaining term $f_{0}$ is estimator of the residual spectrum at frequency zero.

\section{Kwiatkowski-Phillips-Schmidt-Shin tests (KPSS)}

The alternative test introduced in 1992 by Kwiatkowski, Phillips, Schmidt and Shin, and called henceforth the KPSS test has a null of stationarity of a series around either mean or a linear trend; and the alternative assumes that a series is non-stationary due to presence of a unit root. In this respect it is innovative in comparison with earlier Dickey-Fuller test, or Perron type tests, in which null hypothesis assumes presence of a unit root. In the KPSS model, series of observations is represented as a sum of three components: deterministic trend, a random walk, and a stationary error term. The model has the following form: ${ }^{14}$

$$
\begin{gathered}
\gamma_{t}=\xi t+r_{t}+\varepsilon_{t} \\
r_{t}=r_{t-1}+u_{t}
\end{gathered}
$$

Where $\gamma_{t} \mathrm{t}=1,2, \ldots \ldots$. T denotes series of observations of variable of interest, $\mathrm{t}$-deterministic trend, $r_{t}$ random walk process, $\varepsilon_{t}$ - error term of the first equation, by assumption is stationary, $u_{t}$ denotes an error term of second equation, and by assumption is a series of identically distributed independent random variables of expected value equal to zero and constant variation $\sigma 2 u$. By assumption, an initial value $r_{0}$ of the second equation is a constant and it corresponds to an intercept.

\section{Results and Discussion}

Hypotheses for ADF and PP Tests

$H_{0-}=$ The existence of unit root found in time series data.

$H_{a}=$ The existence of unit root not found in time series data.

Hypotheses for KPSS Tests

$H_{01}=$ The existence of unit root not found in time series data.

$H_{a 1}=$ The existence of unit root found in time series data.

The Augmented Dickey Fuller (ADF) -Phillip Perron test and Kwiatkowski-Phillips-Schmidt-Shin tests detected the stationarityin the time series. The results of ADF and PP tests show the

\footnotetext{
${ }^{13}$ Tripathy, Forecasting Stock Market Volatility: Evidence From Six Emerging Markets, Journal of International Business and Economy: 69-93

${ }^{14}$ Empirical power of the Kwiatkowski-Phillips-Schmidt-Shin test:Department of Applied Econometrics Working Papers Warsaw School of Economics , Poland
} 
smaller test statistic than the critical value at $5 \%$ level of significance at level with trend and intercept except Kotak Mahindra bank which is found to be stationary in both level and first difference. Hence the null hypothesis $H_{0}$ is accepted and concluded that the prices series is not stationary, but while the data is converted in to first difference the test statistic is larger than the critical value at $5 \%$ levelwith trend and intercept. Hence the null hypothesis $H_{0}$ is rejected and concluded that the prices series is stationary and not following random walk model. The test statistic of Kwiatkowski-Phillips-Schmidt-Shin test is smaller than the critical value for all the banking stocks in first difference with intercept and trend. Therefore the null hypothesis $H_{01}$ could not be rejected. It is determined that the all the 12 stocks and bank index do not follow random walk hypothesis.

\section{Conclusion and Recommendations}

The paper enumerates the global and Indian economic competitive mechanism and the structure and growth of Indian banking sector in the era of globalization. Besides the paper deals about the relevance and irrelevance approaches of weak form market efficiency and the contemporary empirical studies on testing weak form efficiency conducted in emerging markets. The mixed evidences have been witnessed in the recent studies. Inspite the present study reveals that the NSE - Bankex and 12banking stocks are found to be weak form inefficient. Eventually, it is concluded that thesmart money is not offsetting the behavior and investment style of irrational optimist and pessimist. Hence the rational utility maximization is not always possible. So that trading strategies can be formulated by investors to gain abnormal returns. There is possibility of earning extra income on the account of market inefficiency.

\section{References}

Worthington, A. C., \& Higgs, H. (2005). Weak-form market efficiency in Asian emerging and developed equity markets: Comparative tests of random walk behaviour.

Haque, A., Liu, H. C., \& Nisa, F. U. (2011). Testing the weak form efficiency of Pakistani stock market (2000-2010). International Journal of Economics and Financial Issues, 1(4), 153162.

Khan, A. Q., Ikram, S., \& Mehtab, M. (2011). Testing weak form market efficiency of Indian capital market: A case of national stock exchange (NSE) and Bombay stock exchange (BSE). African Journal of Marketing Management, 3(6), 115-127.

Abushammala, S. N. (2011). Testing the weak form efficiency of Palestine exchange. International Journal of Economics and Finance, 3(6), 244-253.

Al Ashikh, A. I. (2012). Testing the weak-form of efficient market hypothesis and the day-ofthe-week effect in Saudi stock exchange: Linear approach. International review of Business research papers, 8(6), 27-54.

Shaker, A. T. M. (2013). Testing the weak-form efficiency of the Finnish and Swedish stock markets. European Journal of Business and Social Sciences, 2(9), 176-185.

Shiller, I., \& Radikoko, I. (2014). Testing weak-form market efficiency on the TSX. Journal of Applied Business Research (JABR), 30(3), 647-658.

Ananzeh, I. E. N. (2014). Testing the weak form of efficient market hypothesis: Empirical evidence from Jordan. International Business and Management, 9(2), 119-123. 
Mobarek, A., \& Keasey, K. (2000, May). Weak-form market efficiency of an emerging Market: Evidence from Dhaka Stock Market of Bangladesh. In ENBS Conference held on Oslo (pp. 1-30).

Moustafa, M. A. (2004). Testing the weak-form efficiency of the United Arab Emirates stock market. Available at SSRN 551102.

Ajao, M. G., \& Osayuwu, R. (2012). Testing the weak form of efficient market hypothesis in Nigerian capital market. Accounting and Finance Research, 1(1), 169-179.

Phukubje, M. P., \& Moholwa, M. B. (2006). Testing for weak-form efficiency in South African futures markets for wheat and sunflower seeds. Agrekon, 45(2), 198-213.

Shiller, R. J. (2003). From efficient markets theory to behavioral finance. Journal of economic perspectives, 17(1), 83-104.

Gupta, R., \& Yang, J. (2011). Testing weak form efficiency in the Indian capital market. International Research Journal of Finance and Economics, 75(1), 108-119.

Niblock, S., \& Sloan, K. (2007, September). Are Chinese stock markets weak-form efficient. In 12th Finsia-Melbourne Centre for Financial Studies Banking and Finance Conference, Melbourne.

Nisar, S., \& Hanif, M. (2012). Testing weak form of efficient market hypothesis: empirical evidence from South Asia. World Applied Sciences Journal, 17(4), 414-427.

Manickam, T., \& Madhumitha, R. (2015). Random Walk Investigation in Indian Market with special reference to S\&P Nifty-Fifty Stocks. International Journal of Finance \& Banking Studies (2147-4486), 4(4), 52-61.

Gimba, V. K. (2012). Testing the weak-form efficiency market hypothesis: Evidence from Nigerian stock market. CBN Journal of Applied Statistics, 3(1), 117-136.

Khrapko, V. (2013). Testing the weak-form efficiency hypothesis in the ukrainian stock market versus those of the USA, Russia, and Poland. Ekonomika, 92(2), 108-121. 
INTERNATIONAL JOURNAL OF ACADEMIC RESEARCH IN BUSINESS AND SOCIAL SCIENCES Vol. 11, No. 5, 2021, E-ISSN: 2222-6990 (c) 2021 HRMARS

Unit Root Test Results under Augmented Dickey - Fuller -Phillip Perron

\begin{tabular}{|c|c|c|c|c|c|c|c|c|}
\hline & \multicolumn{4}{|c|}{ ADF TEST RESULTS } & \multicolumn{4}{|c|}{ PP TEST RESULTS } \\
\hline & \multicolumn{2}{|l|}{ LEVEL } & \multicolumn{2}{|c|}{ FIRST DIFFERENCE } & \multicolumn{2}{|l|}{ LEVEL } & \multicolumn{2}{|c|}{ FIRST DIFFERENCE } \\
\hline & $\begin{array}{l}\text { TEST } \\
\text { STAT }\end{array}$ & $\begin{array}{l}\text { CRITICAL } \\
\text { VALUE }\end{array}$ & $\begin{array}{l}\text { TEST } \\
\text { STAT }\end{array}$ & $\begin{array}{l}\text { CRITICAL } \\
\text { VALUE }\end{array}$ & $\begin{array}{l}\text { TEST } \\
\text { STAT }\end{array}$ & $\begin{array}{l}\text { CRITICAL } \\
\text { VALUE }\end{array}$ & $\begin{array}{l}\text { TEST } \\
\text { STAT }\end{array}$ & $\begin{array}{l}\text { CRITICAL } \\
\text { VALUE }\end{array}$ \\
\hline BANK INDEX & 3.059051 & $\begin{array}{l}- \\
3.412135\end{array}$ & $\begin{array}{l}- \\
39.74926\end{array}$ & $\begin{array}{l}- \\
3.412135\end{array}$ & $-\overline{2.832733}$ & 3.412133 & $\begin{array}{l} \\
39.56513\end{array}$ & $\begin{array}{l}- \\
3.412135\end{array}$ \\
\hline KOTAK BANK & $\begin{array}{l}- \\
3.732109\end{array}$ & $\begin{array}{l}- \\
3.412133\end{array}$ & 42.77393 & $\begin{array}{l}- \\
3.412135\end{array}$ & $\begin{array}{l}- \\
3.692193\end{array}$ & $\begin{array}{l} \\
3.412133\end{array}$ & $\begin{array}{l}- \\
42.80146\end{array}$ & $\begin{array}{l}- \\
3.412135\end{array}$ \\
\hline HDFCBANK & $\begin{array}{l}- \\
2.115201\end{array}$ & $\begin{array}{l}- \\
3.412133\end{array}$ & $\begin{array}{l}- \\
44.04961\end{array}$ & $\begin{array}{l}- \\
3.412135\end{array}$ & $\begin{array}{l} \\
2.133818\end{array}$ & $\begin{array}{l}- \\
3.412133\end{array}$ & $\begin{array}{l}- \\
44.04963\end{array}$ & $\begin{array}{l}- \\
3.412135\end{array}$ \\
\hline $\begin{array}{l}\text { STATE BANK } \\
\text { OF INDIA }\end{array}$ & $\begin{array}{l}- \\
1.980565\end{array}$ & $\begin{array}{l}- \\
3.412133\end{array}$ & $\begin{array}{l}- \\
41.86063\end{array}$ & $\begin{array}{l}- \\
3.412135\end{array}$ & $\begin{array}{l}- \\
1.963557\end{array}$ & $\begin{array}{l}- \\
3.412133\end{array}$ & $\begin{array}{l}- \\
41.81716\end{array}$ & $\begin{array}{l}- \\
3.412135\end{array}$ \\
\hline $\mathrm{ICICI}$ BANK & $\begin{array}{l}- \\
2.434230\end{array}$ & $\begin{array}{l}- \\
3.412133 \\
\end{array}$ & $\begin{array}{l}- \\
43.19368\end{array}$ & 3.412135 & - 2.467041 & - & $\begin{array}{l}- \\
43.18715\end{array}$ & $\begin{array}{l}- \\
3.412135\end{array}$ \\
\hline PNBANK & $\begin{array}{l}- \\
1.588007\end{array}$ & $\begin{array}{l}- \\
3.412133\end{array}$ & $\begin{array}{l}- \\
42.84054\end{array}$ & $\begin{array}{l}- \\
3.412135\end{array}$ & 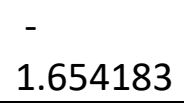 & - 3.412133 & - & 3.412135 \\
\hline AXIS BANK & - & $\begin{array}{l}- \\
3.412133\end{array}$ & $\begin{array}{l}- \\
42.80420\end{array}$ & - & - & -4.412133 & 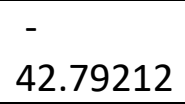 & $\begin{array}{l}- \\
3.412135\end{array}$ \\
\hline $\begin{array}{l}\text { INDUSIND } \\
\text { BANK }\end{array}$ & $\begin{array}{l}- \\
1.798771\end{array}$ & $\begin{array}{l}- \\
3.412133\end{array}$ & $\begin{array}{l}- \\
42.66994\end{array}$ & 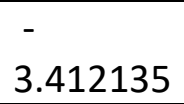 & $-\overline{1.761952}$ & -4.412133 & $-\overline{42.66336}$ & $\begin{array}{l}- \\
3.412135\end{array}$ \\
\hline YESBANK & $\begin{array}{l}- \\
2.677625\end{array}$ & 3.412136 & $\begin{array}{l}- \\
31.79688\end{array}$ & 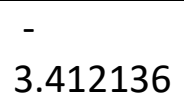 & $-\overline{2.662533}$ & 3.412133 & $\begin{array}{l}- \\
39.89573\end{array}$ & $\begin{array}{l}- \\
3.412135\end{array}$ \\
\hline $\begin{array}{l}\text { BARODA } \\
\text { BANK }\end{array}$ & $\begin{array}{l}- \\
1.678175\end{array}$ & $\begin{array}{l}- \\
3.412133\end{array}$ & $\begin{array}{l}- \\
44.69080\end{array}$ & $\begin{array}{l}- \\
3.412135\end{array}$ & $\begin{array}{l}- \\
1.658474\end{array}$ & $\begin{array}{l} \\
3.412133\end{array}$ & $\begin{array}{l}- \\
44.69393\end{array}$ & $\begin{array}{l}- \\
3.412135\end{array}$ \\
\hline $\begin{array}{l}\text { BANK OF } \\
\text { INDIA }\end{array}$ & $\begin{array}{l}- \\
2.594810\end{array}$ & $\begin{array}{l} \\
3.412135\end{array}$ & $\begin{array}{l}- \\
40.92910\end{array}$ & $\begin{array}{l}- \\
3.412135\end{array}$ & $\begin{array}{l}- \\
2.494924\end{array}$ & $\begin{array}{l}- \\
3.412133\end{array}$ & $\begin{array}{l}- \\
40.82689\end{array}$ & $\begin{array}{l}- \\
3.412135\end{array}$ \\
\hline $\begin{array}{l}\text { CANARA } \\
\text { BANK }\end{array}$ & $\begin{array}{l}- \\
1.806668\end{array}$ & $\begin{array}{l}- \\
3.412135\end{array}$ & $\begin{array}{l}- \\
40.67577\end{array}$ & $\begin{array}{l}- \\
3.412135\end{array}$ & $\begin{array}{l}- \\
1.759075\end{array}$ & $\begin{array}{l}- \\
3.412133\end{array}$ & $\begin{array}{l}- \\
40.65472\end{array}$ & $\begin{array}{l}- \\
3.412135\end{array}$ \\
\hline $\begin{array}{l}\text { FEDERAL } \\
\text { BANK }\end{array}$ & $\begin{array}{l}- \\
1.326179\end{array}$ & $\begin{array}{l}- \\
3.412135\end{array}$ & $\begin{array}{l}- \\
41.25958\end{array}$ & $\begin{array}{l}- \\
3.412135\end{array}$ & $\begin{array}{l}- \\
1.142485\end{array}$ & $\begin{array}{l}- \\
3.412133\end{array}$ & $\begin{array}{l}- \\
41.21114\end{array}$ & $\begin{array}{l}- \\
3.412135\end{array}$ \\
\hline
\end{tabular}


INTERNATIONAL JOURNAL OF ACADEMIC RESEARCH IN BUSINESS AND SOCIAL SCIENCES Vol. 11, No. 5, 2021, E-ISSN: 2222-6990 (C 2021 HRMARS

Unit Root Test Results Under Kwiatkowski-Phillips-Schmidt-Shin Tests

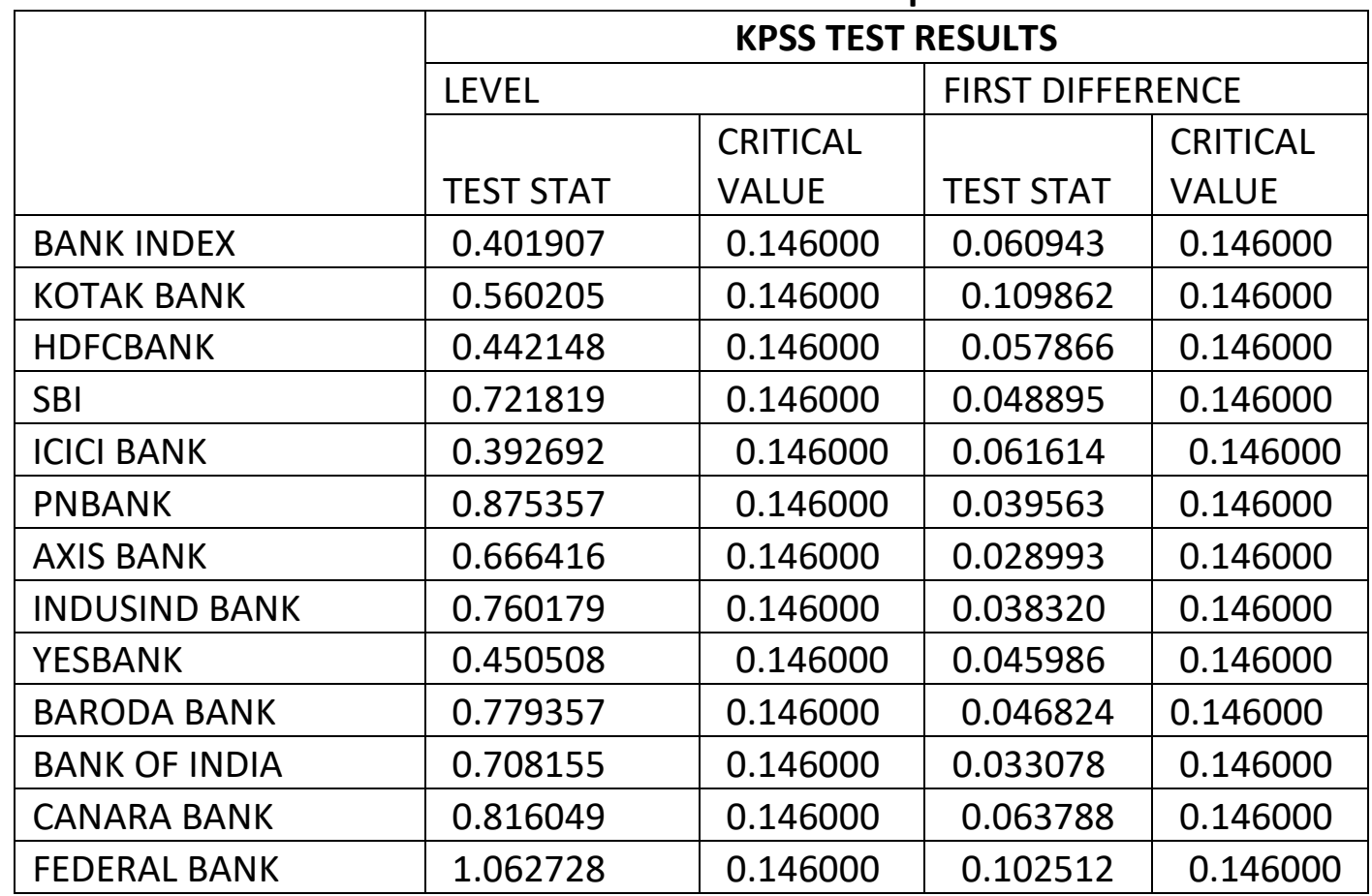

